\title{
From genes towards products and the significance of gene delivery
}

\author{
Magnus Hertzberg \\ From IUFRO Tree Biotechnology Conference 2011: From Genomes to Integration and Delivery \\ Arraial d'Ajuda, Bahia, Brazil. 26 June - 2 July 2011
}

SweTree Technologies is a plant and forest biotechnology company providing products and technologies to improve the productivity and performance properties of plants, wood and fiber for forestry and fiber related industries.

In the area of Biotech Trees, we have been testing and developing genes and biotech trees. Since 2002 we have successfully screened well over one thousand genes in our gene testing program. The program has been mainly directed towards increased growth, improved wood properties and stress tolerance. The current outcome of this program will be presented. The primary gene developing program is performed in hybrid aspen for which we have a very efficient transformation protocol. However for practical tree biotechnology the genes and DNA constructs have to be transformed into the best commercial clones. Therefore we have been setting up efficient transformation protocols for both Eucalyptus and Populus elite clones. Another crucial part of a practical tree biotechnology program is to test the GM trees with commercially interesting genes under field conditions. We have initiated field trials and plan to have over 35 different types of transgenic trees in field trials by the end of this year. These field experiments are performed by SweTree or in collaboration with academic partners. The importance and requirements for elite clone transformation and field trials will be discussed in the presentation.

Published: 13 September 2011

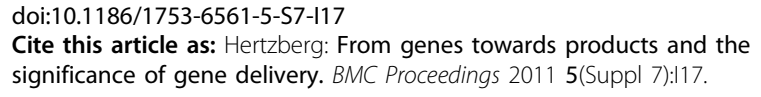

Submit your next manuscript to BioMed Central and take full advantage of:

- Convenient online submission

- Thorough peer review

- No space constraints or color figure charges

- Immediate publication on acceptance

- Inclusion in PubMed, CAS, Scopus and Google Scholar

- Research which is freely available for redistribution
() Bïomed Central
C Biomed Central

(c) 2011 Hertzberg; licensee BioMed Central Ltd. This is an open access article distributed under the terms of the Creative Commons Attribution License (http://creativecommons.org/licenses/by/2.0), which permits unrestricted use, distribution, and reproduction in any medium, provided the original work is properly cited. 